\title{
The Research \& Discussion about Application-oriented Undergraduate Colleges Practical Teaching Center Establishment
}

\author{
CHEN Zhuo QIN Lu-fang \\ School of Mechanical and Electrical Engineering, Xuzhou Institute of technology, Xuzhou 221008, \\ Jiangsu, China \\ 346591653@163.com
}

Keywords: Application-oriented; Undergraduate Colleges; Practical Teaching Center; construction.

\begin{abstract}
According to the problems of application-type regular university practical teaching center establishment, this article studies and discusses in five respects: transforming education concepts and attention to practical teaching, management system perfection and innovating operation mechanism, strengthening construction of teaching staff and reasonable arrangement on practical teaching, development of creative thinking and cultivate creative talents, increase of hardware investment and positive serving society.
\end{abstract}

\section{Introduction}

Predecessors of existing practical teaching centers of application-oriented undergraduate colleges are mostly metalworking practice workshops and practice factories of former higher vocational colleges. Take Xuzhou Institute of Technology where the author is studying as example, this school was merged by three higher vocational colleges and it is a typical application-oriented undergraduate colleges. In order to adapt to training plans of application-oriented talents, the college strengthens practical teaching links. Except for reinforcing construction of laboratories, the college also extends its engineering training center. The engineering training center, belonging to Electromechanical College, covering an area of 1,300 square meters and possessing equipment investment of totally RMB 6 million, is mainly for practice teaching and relevant trainings for students of Electromechanical College. While as for some higher vocational colleges, because of more supports to higher vocational colleges from the country and training objective of the higher vocational colleges is to cultivate talents who possess certain operating skills and can works at the front line of factories, most of these colleges reinforce construction of practical training centers, and they have advantages in floor area, equipment quantity and quality and faculty over application-oriented undergraduate colleges. In general, no matter by comparison to higher vocational colleges or out of their own teaching needs, some problems still founded in construction of practical training centers of application-oriented undergraduates, specifically are:

\section{Orientation of practical training center remains to be improved.}

Leaders in charge of practical centers think that current undergraduate teaching level evaluation index system has clear and specific index for laboratory construction, while it has no exclusive index for school practical training centers, so it is necessary to establish practical training centers though, compared with construction of department laboratories and off-campus practice bases, significance of establishing practical training centers is not that great. From the aspect of teaching 
management functional departments, due to influences of profound traditional education ideas and plus with reasons that the departments are busy with expanding enrollment scale in recent years, a few teaching management personnel has biased understanding that "university education should place theory teaching first and practical teaching second". While some of the teachers and students are biased against practical teaching, so neglect of practical teaching often occurs.

Construction of teaching staff of practical centers is insufficient. Teachers play the leading role in cultivation of application-oriented talents. Renewal of teaching concept, formulation and implementation of teaching programme, teaching quality control system and management operation system of practical teaching base all rely on teachers. Teachers guiding practical trainings should further perfect their own knowledge structure. Compared with cultivation of skilled talents of higher vocational college, cultivation of application-oriented talents puts forward new requirements for knowledge structure of teachers. Teachers engaged in practical training guide should possess not only solid theoretical basis, but also abundant practical training experience and process knowledge and abilities to analyze and solve engineering practical problems. Teachers should not only be qualified for teaching specialty theoretical courses but also qualified for guiding production practice and practical operation, namely, teachers should be competent at both platforms and machines. But for now, "double qualified" teachers are insufficient in quantity, lower in quality, weak in adaptability and incomplete in categories, which are "bottlenecks" for construction of practical teaching system.

Hardware of practical training centers remains to be increased. "College enrollment expansion plan” leads to dramatic increase of students, which gives rise to shortage of school buildings, crowed teaching space, seriously insufficient of practical training area per student and practical training equipment per student, shortage of practical teaching funds and sharply decrease of practical teaching hours as results, therefore it becomes more difficult to find places to establish campus practical training bases. Student practices and practical teaching have to adopt expedients of merger, cut-down, simulation and even "replacing practices with lectures". Practical teaching courses either be replaced by classroom multimedia presentation teaching or be stopped straightforwardly. Many teachings which need hand-on operations to gain experience and knowledge are simplified to presentations with images, texts and sound images. Due to insufficient operating skill trainings from engineering education, practical operation abilities of students decline generally.

Management system of practical training centers remains to be completed. What kind of management system do practical training centers of application-oriented undergraduate colleges establish is a topic worth further discussion. Based on the current situation, firstly it can be found that practical training centers belong to secondary colleges. For example, practical training center of Xuzhou Institute of Technology attaches to Electromechanical College systematically, and the funds are mainly provided to Electromechanical College while funds to the practical training center are insufficient relatively. Meanwhile, contents of courses of the practical training center are mainly specialties of Electromechanical College, which leads to problems in further investment and development of the practical training center. Secondly the practical training center, directly subordinate to the school, is the secondary teaching department of the school and implements two-level management by school and center. Funds are from the school, teaching contents and teaching objects are open to the whole school, constructions of laboratories, teaching staff and management team, experiment arrangement, experiment expenditures, position recruitment, performance appraisal, assets and equipment are managed comprehensively. 
Practical training centers play great roles in cultivating application-oriented undergraduate talents adapting to social needs. Aimed at problems found in the research and for reference of experience at home and abroad, the author put forwards a number of countermeasures and suggestions for strengthening construction of practical training centers of application-oriented undergraduate colleges, as follows:

\section{Changing educational concept and attaching importance to practical teaching}

In order to solve problems existing in practical training centers of application-oriented undergraduate colleges, firstly, educational concept should be changed and awareness to practical teaching should be improved. Experts studying educational concept change of higher engineering education think that: a. educational concept taking passing on knowledge as educational objective should be changed to educational concept taking cultivating innovative thinking and ability as educational objective and regarding knowledge inheriting serves innovation; b. cognitive-test-oriented experiment and engineering practical teaching system should be reformed to new teaching system attaching importance to comprehensive, designing and research experiments to cultivate innovative thinking and ability and regarding cognitive experiment serves designing and innovative experiment; c. mode of setting up experiments and laboratories with single course or single specialty should be reformed to the new mode of setting up experiments and laboratories (centers) with subject groups or specialty category so as to ensure realization of new system of experiment and engineering practical teaching; d. new experimental apparatus and equipment designed with new thinking should be encouraged to form a mechanism that experiment teaching contents and system renew along with the times [1].

Through studies and discussions, teachers and students in the whole school should realize that: in order to implement the educational objective of rendering solid foundation, wide scope of knowledge, strong ability and high quality to students, not only theoretical teaching should be strengthened, but also practical teaching in view of the particularly important role of practical teaching in cultivating innovative spirit and improving practical ability of students. Strengthening practical teaching should not be simply regarded as increasing practical teaching hours or setting more practical teaching programs. Strengthening practical teaching is reflected in scientifically handling relationship between practical teaching and theoretical teaching, which relationship is neither subordinate nor parallel while it is their combination which should be emphasized. A new system of integrating practical teaching and theoretical teaching should be sought with systematic view so as to give full play of the overall function of practical teaching [2]. Only by realizing the significant role of practical teaching in cultivating application-oriented talents at present times, can ideological basis for construction of practical training centers be stashed.

\section{Perfecting management system and innovating operating mechanism}

Management system of practical training centers plays a key role in normal operation and development of practical training centers. Firstly, leaders of schools should be assigned to be in charge of the practical training centers, establishment and operation of practical training centers should be listed in the agenda of the leading groups to implement guiding thought, job requirements, blueprint, funds investment, key equipment purchase, teaching staff construction and management organization of practical training work. Especially formulating all kinds of preferential policy of practical training center, including professional title appraisal, teachers' further education and increasing funds, for practical training centers, but it will be difficult if these ideas are not up to the 
heist decision-making level. It turns out that whether practical training centers even the entire practical teaching can enter into the highest decision-making level of the school directly influences healthy and rapid development of practical training centers. Secondly, practical training centers should implement director's responsibility system to specify work post responsibilities of staff, determine operation quota, establish technical files, carry out appraisal activities and carry out necessary rewards and punishments, etc. Thirdly, relationships between practical training centers and other functional departments of schools should be coordinated to let practical training centers cooperate with educational administration department, financial department and all departments, properly formulate practical training class schedules of each semester, and sufficiently and effectively use equipment. Practical training centers should cooperate with asset department to make general account, detailed account, card and register book of instrument and equipment, complete rigorous registration management system of instrument and equipment to register all increase and decrease of instrument and equipment, and so as to ensure account consistent with other account and the facts [3]. Fourthly, system and regulations should be formulated to improve management level of practical training centers. Practical training centers not only need construction, but also all kinds of regulations and system to carry out standardized and scientific management. In order to complete practical training management system, manuals, methods and systems like Manual for Practical Training Center Director, Management Method of Teaching Instruments, Borrowing Method of Instrument and Equipment, Management Method of Instrument and Equipment Maintenance, and Rules for Practical Training of Students. A complete system network can be formed through these measures so as to systematically guarantee normal operation of practical training work and investment benefits of practical training center establishment, thus ensuring scientific, systematic and standardized management of practical training centers [4]. Fifthly, archive work of practical training center should be done properly. Practical center archives refer to different forms of historical records such as all kinds of paper documents, electronic documents, diagrams and sound images kept during process of managing, establishing and carrying out practical training activities of all practical training rooms of the practical training center which are of preservation value to the practical training rooms and the school. Practical training achieves should be objective, authentic, systematic and comprehensive, and the archives should be kept timely, regularly, orderly and safely.

Operation mechanism of practical teaching center remains to be innovative as well. The operation of traditional practical teaching center is closed-end. Except for opening at stipulated teaching hour, the center is always closed in the other time, resulting in a very low use ratio in equipment and site. As to each of practical training course, specific provisions on times of practical training, hour and period are contained. Therefore, there is no flexible time to carry out practical training for students. Application-oriented undergraduate colleges should pay much attention to train students' practice ability. Thus, practical teaching center should open the site more frequently, lower the threshold to students, and change closed-end management as open-end management according to training objective of school.

\section{Strengthening teaching staff construction and reasonably arranging practical trainings}

Qualities and structures of existing enterprises and social engineering technicians are insufficient in many aspects, such as aging of knowledge and dated ideology, weak innovative consciousness and innovative ability and shortage of compound-type and entrepreneurial talents, etc. Tracing to its source, one of the important reasons is lack of trainings and cultivations on these aspects when they studied in higher colleges and it is related to quality of college teachers. Therefore, teaching teams 
of practical training centers remains to be improved and their knowledge capability structure needs to be improved as well.

The measures include: one is to select some young technicians who possess better cultural foundations and give them systematic specialized knowledge trainings, the second is to adopt on-the-job training, and the third is to regularly carry out teaching methodology exchange activities and teach-and-learn-from-each-other activities among practice guidance personnel so as to continuously improve guidance level of practical teaching. In addition, practical trainings should combine design and manufacture of teaching products and scientific research as far as possible. This method can improve engineering practice quality of students during process of real products, and improve professional quality of teachers during the process of fine machining and assembly and debugging of products [5].

In view of numerous engineering training teaching contents, choices should be made according to different teaching requirements and appropriate modules and projects should be designed which are extremely important for realizing practical training objective. Application-oriented undergraduate colleges should, aimed at students of different specialties, adopt modular teaching of practical teaching and learning contents of process theory knowledge to divide practical teaching contents into several teaching modules such as heat treatment practice module, machining practice module, numerical control machining module and electrical and electronic practice module, etc. which can be chosen by students of different specialties. Meanwhile, based on different specialties, teaching hours and contents also differ. For example, practical teaching time of machinery specialties is 5 weeks with more and profound teaching contents and longer teaching time, while non-machinery specialties adopt teaching time of 1 to 2 weeks according to their training programs.

\section{Developing innovative thinking and cultivating innovative talents}

As for cultivation of application-oriented undergraduate students, in order for students better adapt to social needs in the future, practical training centers should focus on training and improving innovative thinking, practical ability and comprehensive quality of students. The concept of "taking ability training, quality improvement and innovation consciousness enhancement as cores” should be embodied in practical teaching. Specifically, "three emphases" are reflected in the teaching concept, namely "emphasis on quality, emphasis on comprehensiveness and emphasis on innovation"; "three combinations" are reflected in the teaching method, namely "combination of theory and practice, combination of in-class and after-class and combination of innovation and engineering"; and "three priorities" are reflected in the training objective, namely "consciousness is prior for quality-oriented education; ability is prior in for practical teaching and individuality is prior for innovative cultivation”.

The aim of "popularizing basic engineering knowledge, initiatively building engineering concept, and stimulating interest and curiosity” can be reached by teaching methods of observing teaching models and objects, dismounting trainings of simple machineries, carrying out social investigation practices, classroom discussions and visiting production fields. By teaching modes of operation trainings of all types of work, process design trainings, design and production trainings of innovative works, observing demonstrations of complex process technique, increasing process design units, and requiring students to carry out process design or write innovative thinking reports according to the learned knowledge comprehensively, and advocating students who have strength or energy to spare to make their own designs independently in the training units. The purpose of "self-experience, independent study and free creation" can be reached by teaching mode of combination of in-class and after-class and encouraging students to select interdisciplinary and 
inter-specialty topics independently and experience the whole process of accomplishing a product (project). Technical and innovative talents can be trained by the talent training mode of open-type laboratory, setting new fund, innovative forum, professional skill theme lectures and coalition of college and enterprise.

\section{Increasing hardware input and actively serving the society}

As for construction of practical training centers, except for more input, the colleges should actively coordinate with enterprises and the society, take advantage of social resources and carry out school-enterprise cooperation by international cooperation and exchange or attracting practical teaching materials from domestic enterprises. Meanwhile, practical training centers should participate in production practices through direct external processing, direct industrialization of mature products and R\&D and perfection of products, carry out scientific research and experiments in combination of production, and arrange students to attend trainings in companies according to teaching plans. Relied on scientific researchers of the college, and supported by scientific research projects of the center, production can be improved by conversion of scientific achievements, and scientific research and teaching level of the college can be improved as well, thus combining industry, university and research and better serving the society.

Practical teaching centers play a vital role in cultivating talents in application-oriented undergraduate colleges. We only recognize the problems existing in application-oriented undergraduate colleges practical teaching center establishment, and start from several aspects such as transforming concepts, perfection of system, construction of teaching staff, talents cultivation and increase of investment, so as to construct high level of practical teaching center of application-oriented undergraduate colleges, and to cultivate application-oriented undergraduate talents who can be recognized by the society, so that application-oriented undergraduate colleges can develop a style of its own in higher education system in China.

\section{References}

[1] Tang Yike, Yang Tianyi. Enlightening Innovative Thinking and Reforming Experiment and Engineering Practical Teaching System [J]. Research on Higher Engineering Educaiton, 2002, (4):23-25.

[2] Kang Tao, Hang Huacai, Peng Quankai. Establishing Practical Teaching System and Improving Practical Teaching Level [J]. Journal of Jiangxi Agricultural University (Social Science Edition), 2004, 3(2):138-140.

[3]Zhou Min-fang. Constructing the Laboratories \& Training Centers in the Vocational Schools[J]. Research and Exploration in Laboratory, 2001, 20(3):120-121.

[4] CHENG Xinghuo, XIONG Huiping. Study on the System Reform of Laboratory Management in Higher Vocational Colleges [J]. Joural of Jiangxi Vocational and Technical College of Electricity, 2005, 18(l): 90-92.

[5] Gu Jinliang. Training Model and Enlightenment of the Hong Kong Polytechnic University [J]. China University Teaching, 2001, (6):39-41. 